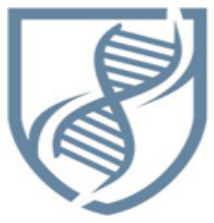

Journal of Bioscience and Applied Research

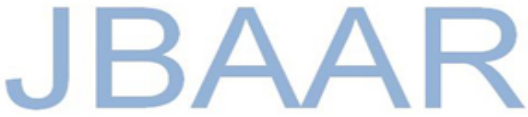

WWW.JBAAR.ORG

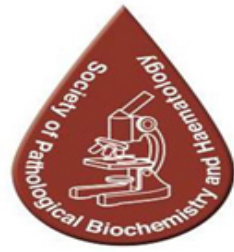

\title{
Bioaccumulation of heavy metals in freshwater snails in relation to lining of water courses in Egypt
}

\author{
${ }^{1}$ Ahmed Abdel Kader, ${ }^{2}$ Gamalat Y. Osman, ${ }^{2}$ Azza H. Mohamed, ${ }^{3}$ Mohamed M. Gharieb, \\ ${ }^{1}$ Nahed M.M. Ismail and ${ }^{1}$ Asmaa Abdel-motleb
}

${ }^{1}$ Environmental Research and Medical Malacology Department,Theodor Bilharz Research Institute, Imbaba, Giza, Egypt ${ }^{2}$ Zoology Department, ${ }^{3}$ Botany Department, Faculty of Science, Menoufia University, Egypt

(Corresponding author email : dr.gyosman@yahoo.com)

\begin{abstract}
The present study was aimed to determine the heavy metal concentrations in whole body of fresh water snails in relation to lining of water courses in two governorates (Behaira (Nubaria) and Giza) Through four successive seasons from Septemper 2013, to October 2014. The obtained results indicated that the electrical conductivity (EC) and iron metal (Fe) showed the highest values and generally the physicochemical measurements indicated that no significant difference between the two tested habitats, however, the conductivity of water in lined water bodies was lower than those of unlined ones. The present study recorded 14 species of snails belonging to class Gastropoda; these species belonged to Pulmonate and Prosobranch snails. The density of all recorded Pulmonate snails in lined sites were lower than those in unlined ones. On the other hand, the abundance of Prosobranch snails was higher in numbers in the lined sites than those in the unlined. In Nubaria the most abundant snails were Melanoides tuberculata and Theodoxus niloticus and exhibited their maximum percentages in the lined (82.15\%) and unlined $(72.34 \%)$ sites during summer, respectively. While, in Giza Governorate Physa acuta snails had the highest percentages among collected snails approximately at all seasons, and exhibited its maximum percentages during spring in lined (90.22\%) and unlined sites (85.38\%). Correlations between physicochemical parameters and the collected snails, revealed that there were different negative or positive correlations depending on the sites of investigation. The bioconcentration factor of heavy metals in snail's soft tissues at the investigated in lined and unlined sites compared to the content of the metals $(\mathrm{Cd}, \mathrm{Cu}, \mathrm{Fe}, \mathrm{Pb}$ and Zinc) in the water showed high variation in BCF values depending on the type of metal and the snail. Generally $P$.
\end{abstract}

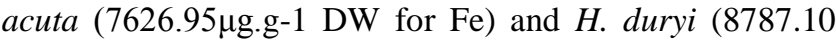
$\mu \mathrm{g} . \mathrm{g}-1 \mathrm{DW}$ for $\mathrm{Cu}$ ) were the highest snails of accumulated metal contents in the tested sites of the two surveyed governorates, respectively.

Keywords: Bioaccumulation, Heavy metals, Fresh water snails, Lining of water courses

\section{Introduction}

Water is a key driver of economic and social development while it also has a basic function in maintaining the integrity of the natural environment. So, lining the canals is one of the most important method to reduce the water losses, appearance, public acceptance, minimize aquatic growth, seepage control, erosion control; safety; and reductions in size of complementary structures, plant transpiration losses, and total annual cost. Benefits include more water for crops, more land for cultivation, protection of low areas from seepage and water logging, enhanced efficacy of molluscicides and reduction in snails (WHO, 1996). Hard surface linings have been extremely effective against certain species of snail vectors (Bonaiti et al., 2011).

During the last decades, environment in general and water in particular have been strongly exposed to the effect of different harmful pollutants, especially heavy metals which has become one of the most serious environmental problems (Wang and Chen, 2006). Metal pollution in aquatic ecosystems, especially river systems, is a major 
environmental concern. Not only this type of pollution cause a decrease in water quality, but subsequently affects all living organisms in the system (Van Dyk, 2003). The ecological importance of metals emanates from their general toxicity and the fact that they are nonbiodegradable and highly persistent and therefore, tend to accumulate in the environmrnt (Ursinyová and Hladiková, 2000 and Coetzee et al., 2002).

Some heavy metals may transform into the persistent metallic compounds with high toxicity, which can be bioaccumulated in the organisms, magnified in the food chain, thus threatening human health. Monitoring and prevention of heavy metal pollution is one of the hot topics in environmental researches. Heavy metal analysis in aquatic organisms can provide important information on the degree of environmental contamination and its impacts (Nahmani et al., 2006; Kanakaraju and Anuar, 2009 and Kowalczyk and Czepiel, 2013). Gastropods are one example of aquatic organisms that can tolerate persistent toxic chemicals, such as metals, to a greater extent than other organisms and have the ability as potential bioindicator and accumulate metals to high concentrations (Zhou et al., 2008; Giarratan et al., 2010; Mahajan, 2015 and Rehman et al., 2016). So, the present study reflects not only the amount of these pollutants in the environment, but also differences in the biotransformation and detoxification processes of these metals, which in snails are specific for different chemical compounds and elements.

\section{Materials and Methods}

\subsection{Study area:}

Samples of water and snails were collected from different lined and unlined water bodies in Behaira (Nubaria) and Giza Governorates, in a total of 14 sites (9 lined and 5 unlined sites) through four successive seasons starting from Septemper 2013, to October 2014. These sites as follows:

\section{Behaira Governorate (Nubaria):}

\section{Lined sites:}

Site 1 : El-Sheikh Zaied canal (cement lining), Site 2 : El- Sedeik Yousif canal (cement lining), Site 3 : Branch of El-Bostan canal - Al-Shohada Village (Cement lining) and Site 4 : Al- Nubaria canal (cement lining).

\section{Unlined sites:}

Site 5 : Naser canal and Site 6: Nagah Sultan canal.

\section{Giza Governorate:}

\section{Lined sites:}

Site 7: Kafer Hakeem: branch of Abo-Shenina canal (bricks or stone lining), Site 8 : King Edress El-Senousy canal (bricks or stone lining), Site 9 : Branch of Kobry ElBalah canal (bricks or stone lining), Site 10: Bani Magdoul canal (cement lining) and Site 11 : Branch of Bani Magdoul canal (rubber lining).

\section{Unlined sites:}

Site 12 : Kafer Hakeem: Abo-Shenina canal, Site 13 : Bani Magdoul: El-Masoudia drain and Site 14 : Monshaat Al-Kanater District- Al-Salebya: El-Mansourya canal.

\subsection{Samples collection:}

\subsubsection{Water samples:}

-Water samples were collected according to Kaufmann et al. (1988) in sterilized plastic containers. The cover of the sterile samples bottle was aseptically removed and the mouth of the bottle was faced upstream (i.e. towards the flow of the water).

- plunging its neck downward $30 \mathrm{~cm}$ below the water's surface and the titled slightly upwards to let it fill completely before carefully replacing the cover.

- The bottle was labeled with the sample code number

- Samples were transported in an ice box to the laboratory for analysis within 12 hours.

\subsubsection{Snail samples:}

Snail sampling was performed through three visits per site using a standard flat wire mesh scoop with mesh size of $2 \mathrm{~cm}$ according to Kariuki et al.( 2004) and Takougang et al. (2008). The collected snails from each sampling site were placed in a numbered plastic aquaria containing some canal water and some amount of aquatic plants and transferred to the laboratory, identified according to Ibrahim et al.(1999), counted and examined for natural infection (Ismail, 2009a and El-Khayat et al., 2013).

\subsection{Determination of Physico-chemical characteristics} of water:

Water temperature and hydrogen ion concentration $(\mathrm{pH})$ were measured directly in the selected watercourses by a portable pH meter (HANNA instrument, HI 9125). Electrical conductivity (EC) and total dissolved solids (TDS) were measured using a portable conductivity meter (HI 9635). Also, dissolved oxygen (DO) was measured using a portable DO meter (HI 8543). All these characteristics were measured on spot at middy, at $20 \mathrm{~cm}$ under the water surface between 9: 00 am to 3: $00 \mathrm{pm}$ and were recorded in the field survey sheets, using procedures in APHA described by Clesceri et al. (1998).

\subsection{Estimation of heavy metals in collected samples :}

Determination of heavy metals in water samples and snail's tissues were performed according to the method of
A.O.A.C.(1995) by using Atomic Absorbtion Spectrophotometer (Solar M 600531 v1 .27) at Central 


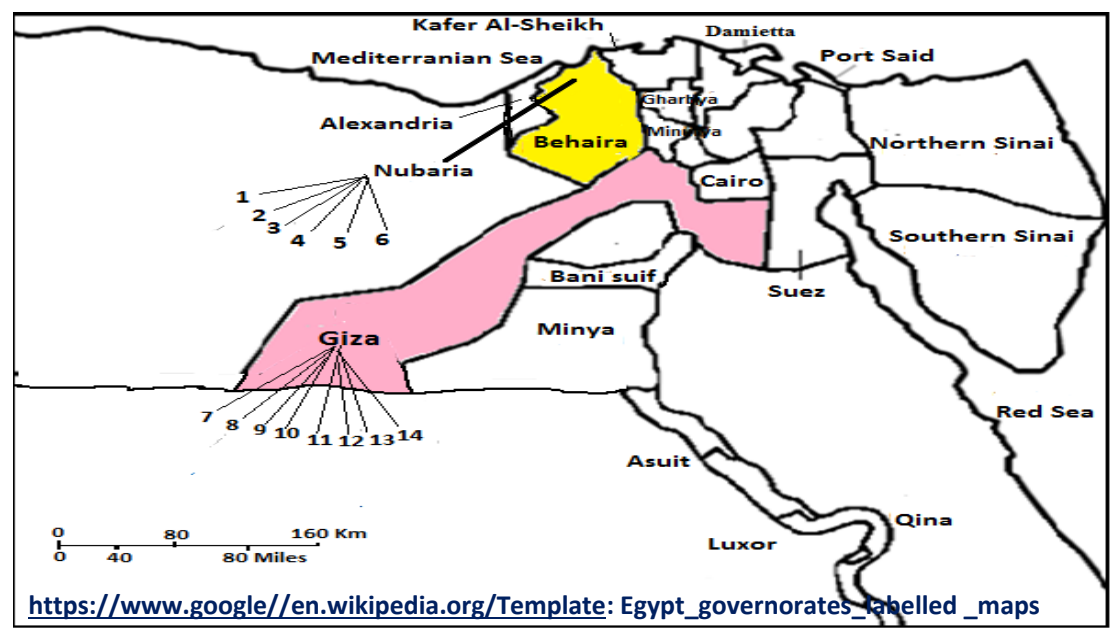

Fig. (1): Sampling sites map.

Agricultural Pesticides Laboratory, Agricultural Research Center ARC, Dokki, Giza, Egypt. The current, wavelength and slit band width of each element were adjusted automatically by the instrument software.

2.4.1. Standards: metals stock standards of $\mathrm{Cd}, \mathrm{Cu}, \mathrm{Fe}, \mathrm{Pb}$ and $\mathrm{Zn}$ were obtained from Merck, Darmstadt, Germany ( Merck's ampoules; $1000 \mathrm{mg}$ ).

2.4.2. Analysis of heavy metals in water: For the analysis of total heavy metals, water samples $(200 \mathrm{ml})$ were digested with $5 \mathrm{ml}$ of di-acid mixture (HNO3: HCIO4: 9:4 ratio) on a hot plate and filtered by Whatman No. 42 filter paper and made up the volume to $50 \mathrm{ml}$ by double distilled $\left(\mathrm{ddH}_{2} \mathrm{O}\right)$.

\subsection{Digestion of snail tissues:}

The snail's soft tissues were separated from their shells carefully, about $0.01 \mathrm{gm}$ of the soft tissues of each snail species, dried in an oven at $50^{\circ} \mathrm{C}$, weighted, and then digested in $1 \mathrm{ml}$ of conc. $\mathrm{HNO}_{3}$ at $70^{\circ} \mathrm{C}$ for $2 \mathrm{~h}$. The digested samples were then diluted with $5 \mathrm{ml}$ ultra pure deionized water for analyzing heavy metals (Federici et al., 2007). The Bioconcentration factor (BCF), which is the ratio of the chemical concentration in an organism or biota to the concentration in water (Gobas and Morrison, 2000), was calculated as follow:

$$
\text { BCF }=\frac{\text { Concentration biota }}{\text { Concentration water }}
$$

\subsection{Statistical Analysis:}

Values of contents of accumulated metals were expressed as mean \pm S.D and statistically analyzed using analysis of variance one way ANOVA (SPSS, version 17.0) to determine the significant differences between different seasons in lined and unlined sites. Correlation between parameters were carried out using the computer program

SPSS (version 17.0). The comparison between means and standard deviations of different parameters were tested for significance using two independent samples $t$-test. The differences were considered significant at $\mathrm{p}<0.05$.

\section{Results}

The present study indicated that, electrical conductivity (EC) $(1773.73 \mu \mathrm{S})$ and iron metal (Fe) (16.59 $\mathrm{ppm}$ ) showed the highest values and were observed during the autumn and summer in unlined and lined sites of Nubaria, respectively (Figure 2A). While, in Giza Governorate the electrical conductivity (EC) $(1175.33 \mu \mathrm{S})$ and iron metal (Fe) (20.69 ppm) were the highest values during spring and autumn in unlined sites, respectively (Figure 2B). The present study also showed seasonal variation in the heavy metals concentrations depending on the type of metal and the sites. Generally from the present results of physicochemical measurements indicated that no significant difference between the two tested habitats (lined and unlined water bodies), however, the conductivity of water in lined water bodies was lower than those of unlined ones. During the study period, a total of 5064 (3656 snails in lined sites +1408 snails in unlined sites) represented by 14 species of snails belonging to class Gastropoda were collected from the lined and unlined sites of investigation in the two surveyed governorates. These species belonged to Pulmonate snails (Lymnaea natalensis, Succinia cleopatra, Planorbis planorbis, Helisoma duryi, Biomphalaria alexandrina, Biomphalaria glabrata, Bulinus truncatus and Physa acuta) and Prosobranch snails (Theodoxus niloticus, Bellamya unicolor, Lanistes carinatus, Gabbiella senaariensis, Melanoides tuberculata and Cleopatra bulimoides). The density of all recorded 
Pulmonate snails in lined sites were lower than those in unlined ones. On the other hand, the abundance of Prosobranch snails was higher in numbers in the lined sites than those in the unlined. In Nubaria the most abundant snails were Melanoides tuberculata and Theodoxus niloticus and exhibited their maximum percentages in the lined and unlined sites during summer, respectively (Figure 3A). While, in Giza Governorate P. acuta snails had the highest percentages among collected snails approximately at all seasons, and exhibited its maximum percentages during spring in lined and unlined sites (Figure 3B). Also, the present results revealed that the richest seasons with different snail species in Nubaria were summer and spring and in Giza Governorate were autumn and winter at lined and unlined sites, respectively.

Concerning the correlations between physicochemical parameters and the collected snails, the obtained data revealed that there was no correlationship between temperature and abundance of snails in lined or unlined sites of Nubaria.

The correlation between physical parameters and snails collected from Giza Governorate revealed that temperature was negatively correlated only with $H$. duryi in some lined sites. Positive correlations were observed between electrical conductivity (EC) and $P$. acuta snails in some lined sites of El-Bahiera (Nubaria) and Giza Governorates, while negative relation was recorded with $L$. carinatus in some unlined sites of Giza Governorate. Moreover, a significant negative correlation was observed between total dissolved solids (TDS) and each of $\quad C$. bulimoides, $P$. acuta and L. carinatus in some unlined sites of Nubaria and Giza Governorates, while positive correlations were observed with $B$. glabrata and $H$. duryi in some lined sites of Giza Governorate. $\mathrm{pH}$ was positively correlated with $H$. dyri in some unlined sites of Giza Governorate, while negative correlations were recorded between $\mathrm{pH}$ and each of ( $H$. dyri and $M$. tuberculata in some lined sites of Nubaria) and (P. acuta and M. tuberculata in some unlined sites of Giza Governorate).Dissolved oxygen was positively correlated with each of $H$. duryi, B. unicolor, B. glabrata and $C$. bulimoides, while it was negatively correlated with $P$. acuta in lined sites of of El-Bahiera (Nubaria) and Giza Governorates. In unlined sites of Nubaria dissolved oxygen showed positive correlations with both of Planorbis Planorbis and Theoduxus niloticus, while no correlations was observed in unlined sites of Giza
Governorate. Concerning the relations between heavy metals ( $\mathrm{Cd}, \mathrm{Cu}, \mathrm{Fe}, \mathrm{Pb}, \mathrm{Zn})$ and the snails in water canals of the studied lined and unlined sites of El-Bahiera (Nubaria) and Giza Governorates, positive correlations were observed, so the more heavy metals concentrations, the more snail species were found. On the other hand, few negative correlations were observed, like: relation between $\mathrm{Cu}$ and each of (P. acuta, M. tuberculata \& L. carinatus), Fe and B. glabrata.

The Comparison of the bioconcentration factor of snail's soft tissues at the investigated in lined and unlined sites compared to the content of the metals $(\mathrm{Cd}, \mathrm{Cu}, \mathrm{Fe}, \mathrm{Pb}$ and Zinc) in the water showed high variation in $\mathrm{BCF}$ values depending on the type of metal and the snail. Generally the iron concentration was the highest metal accumulated in the snail's tissue. The highest snails of accumulated metal contents in the tested sites of El-Bahiera (Nubaria) and Giza Governorates were P. acuta $(7626.95 \mu \mathrm{g}$.g-1 DW for $\mathrm{Fe}$ ) and $H$. duryi $8787.10 \mu \mathrm{g} . \mathrm{g}-1 \mathrm{DW}$ for $\mathrm{Cu}$ ), respectively.

Figure (4A) illustrated that $H$. duryi (9.82)(C), $B$. unicolor (9.35) (H) and Gabbiella senaariensis (17.75)(J) for Fe during winter. B. truncatus (21.47)(E), and $L$. carinatus (13.56)(I) showed the highest BCFs for $\mathrm{Cu}$ during autumn, while $\mathrm{Zn}$ was for B. glabrata (0.054)(D) during Summer. In unlined sites during winter, the highest BCFs were that of of $\mathrm{Zn}$ for (S. cleopatra $(41.67)(\mathbf{A})$ and P. acuta (31.57)(F)) and Fe for (M. tuberculata (25.45)(K) and $C$. bulmoides $(3.35)(\mathbf{L}))$, while during spring $P$. planorbis (10.79)(B) and T. niloticus $(8.03)(\mathbf{G})$ showed the highest BCFs for Fe and $\mathrm{Cd}$, respectively. Also, Figure (4B) of Giza Governorate showed that, the bioconcentration factors in lined sites were high during summer for Cd and Fe with P. planorbis (3.94)(C) and B. unicolor $(0.67)(\mathbf{H})$ snails, respectively. While, $H$. duryi (33.79)(D) and C. bulimoides (0.43)(L) showed higher BCFs for $\mathrm{Cu}$ and $\mathrm{Pb}$ during autumn, respectively. In unlined sites the BCFs were high for Fe with (S. cleopatra (39.60)(B) and B. glabrata (4.69)(F)), for $\mathrm{Zn}$ with ( $L$. natalensis (87.07)(A), P. acuta (87.72)(G) and L.carinatus (6.56)(I)) and M. tuberculata (3.86)(K) for $\mathrm{Cu}$ during winter, while during summer and autumn B. alexandrina $(2.35)(\mathbf{E})$ and $G$. senaariensis $(0.089)(\mathbf{J})$ showed high BCFs for Fe and $\mathrm{Zn}$, respectively. 


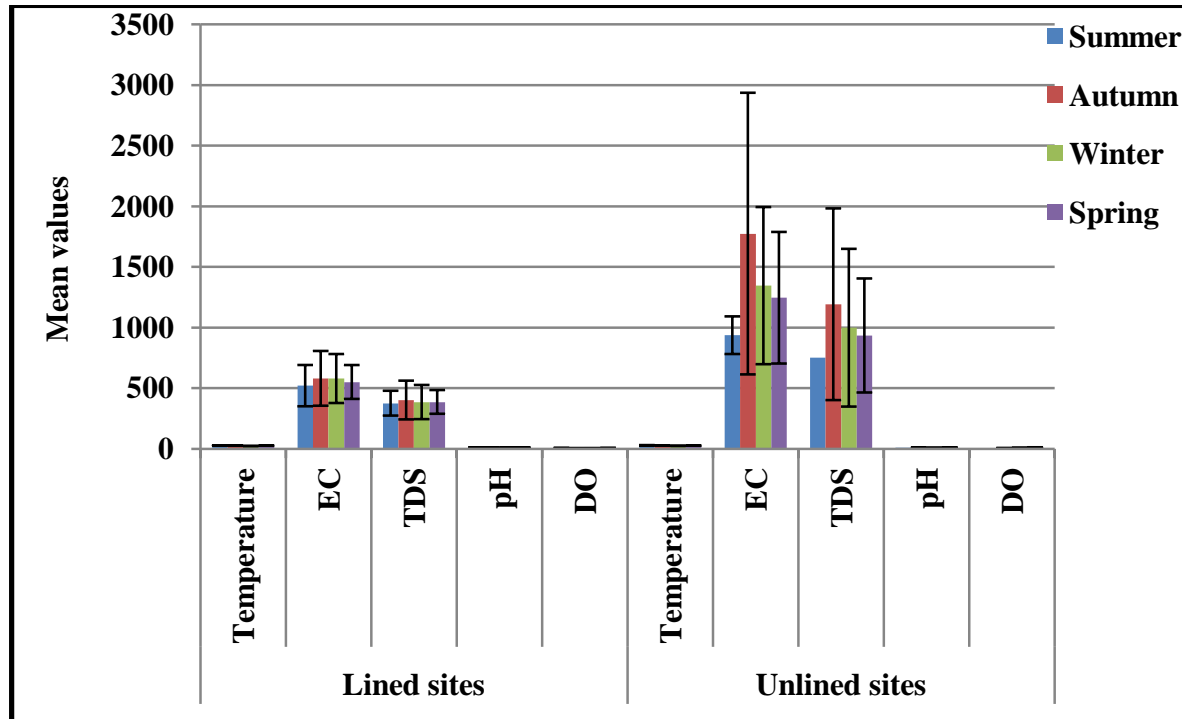

A

Physicochemical parameters

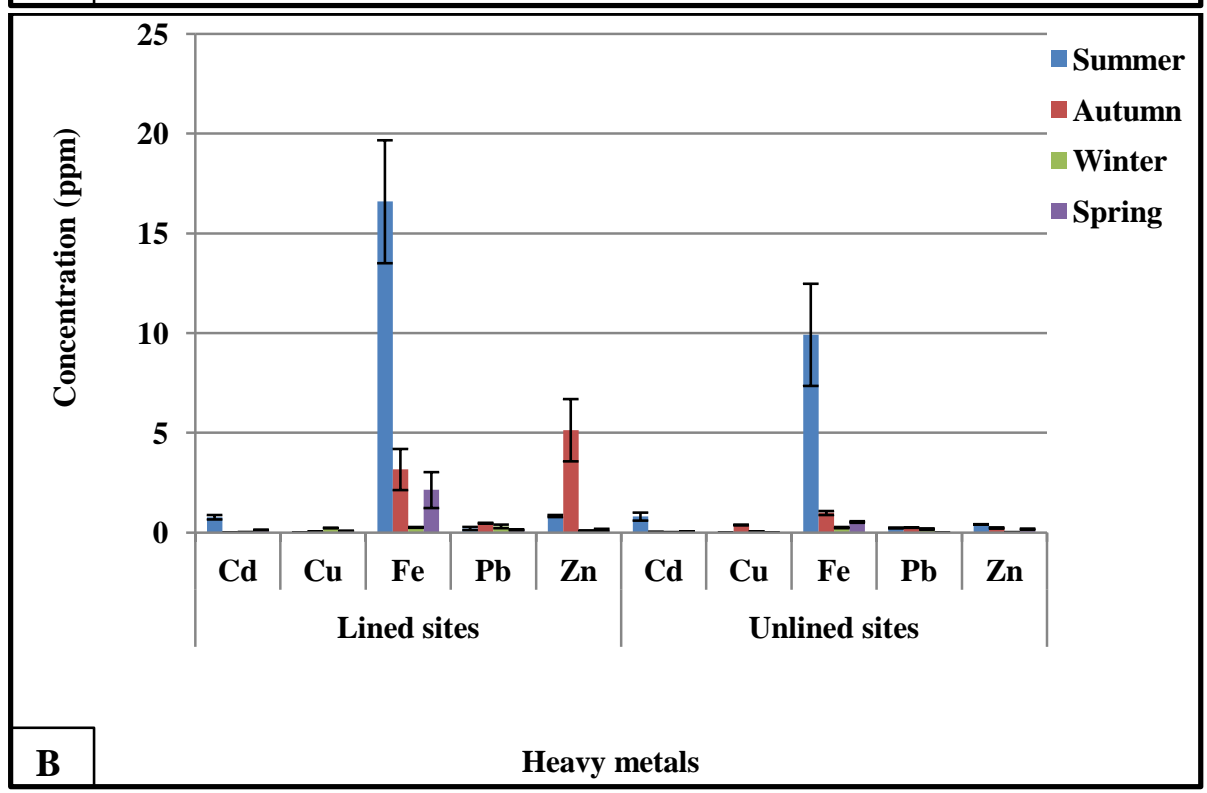

Fig. (2A): The seasonal variations of physicochemical characteristics

(A) and heavy metals (B) in lined and unlined sites of Bahiera

Governorate (Nubaria).

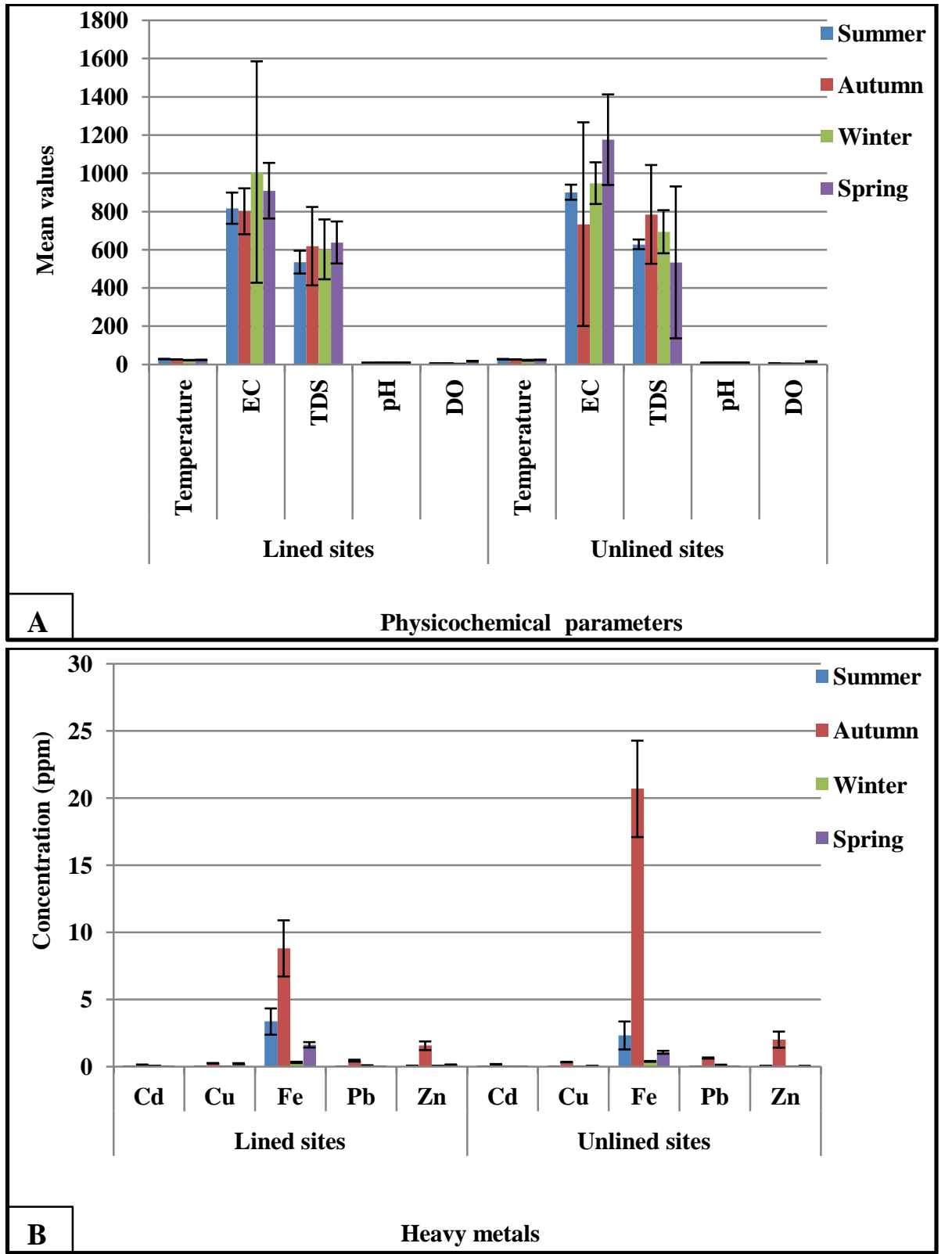

Fig. (2B): The seasonal variations of physicochemical characteristics (A) and heavy metals (B) in lined and unlined sites of Giza Governorate. 

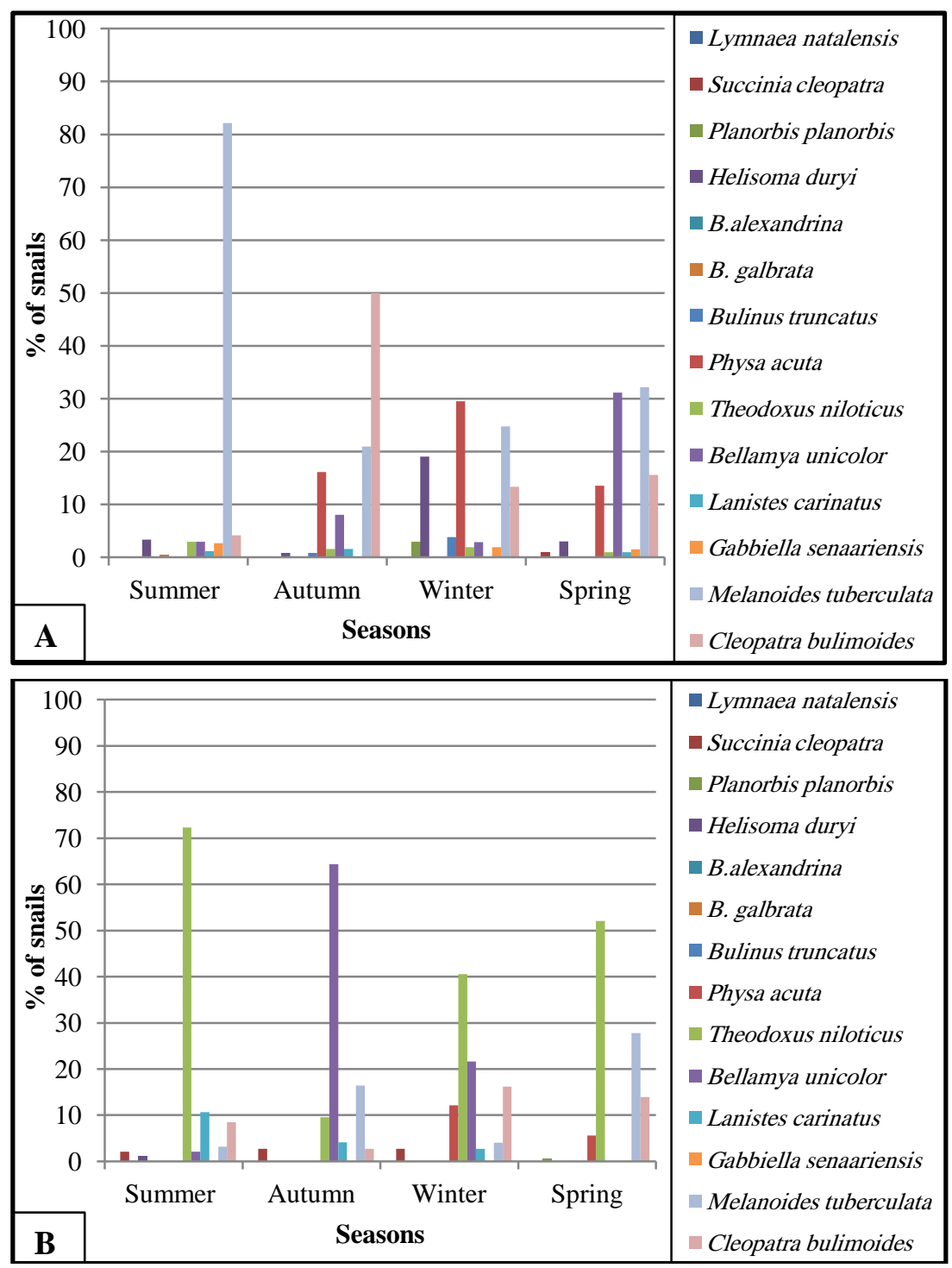

Fig. (3A): Population density of snail species in lined (A) and unlined (B) sites of Bahiera Governorate (Nubaria).
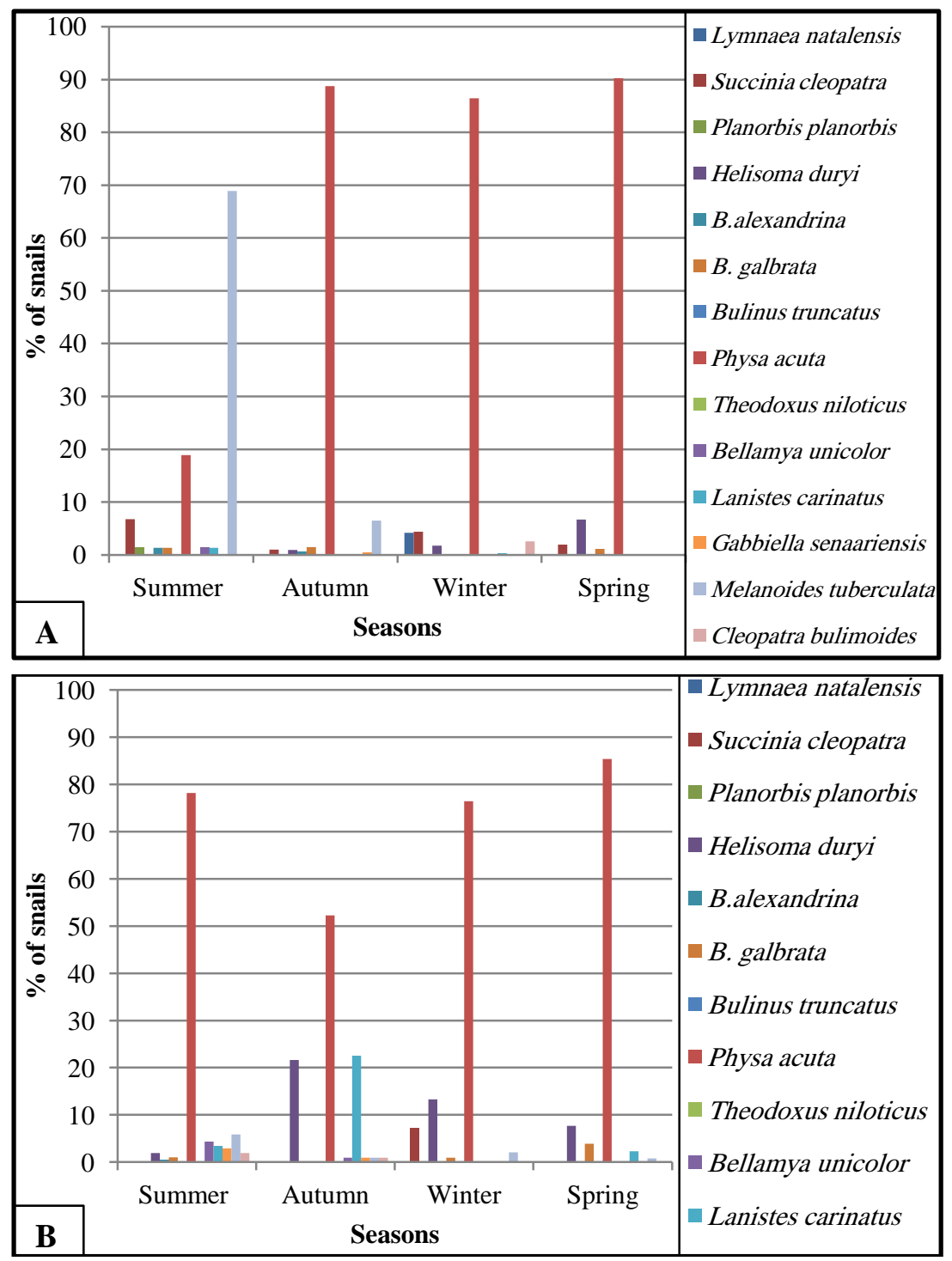

Fig. (3B): Population density of snail species in lined (A) and unlined (B) sites of Giza Governorate. 

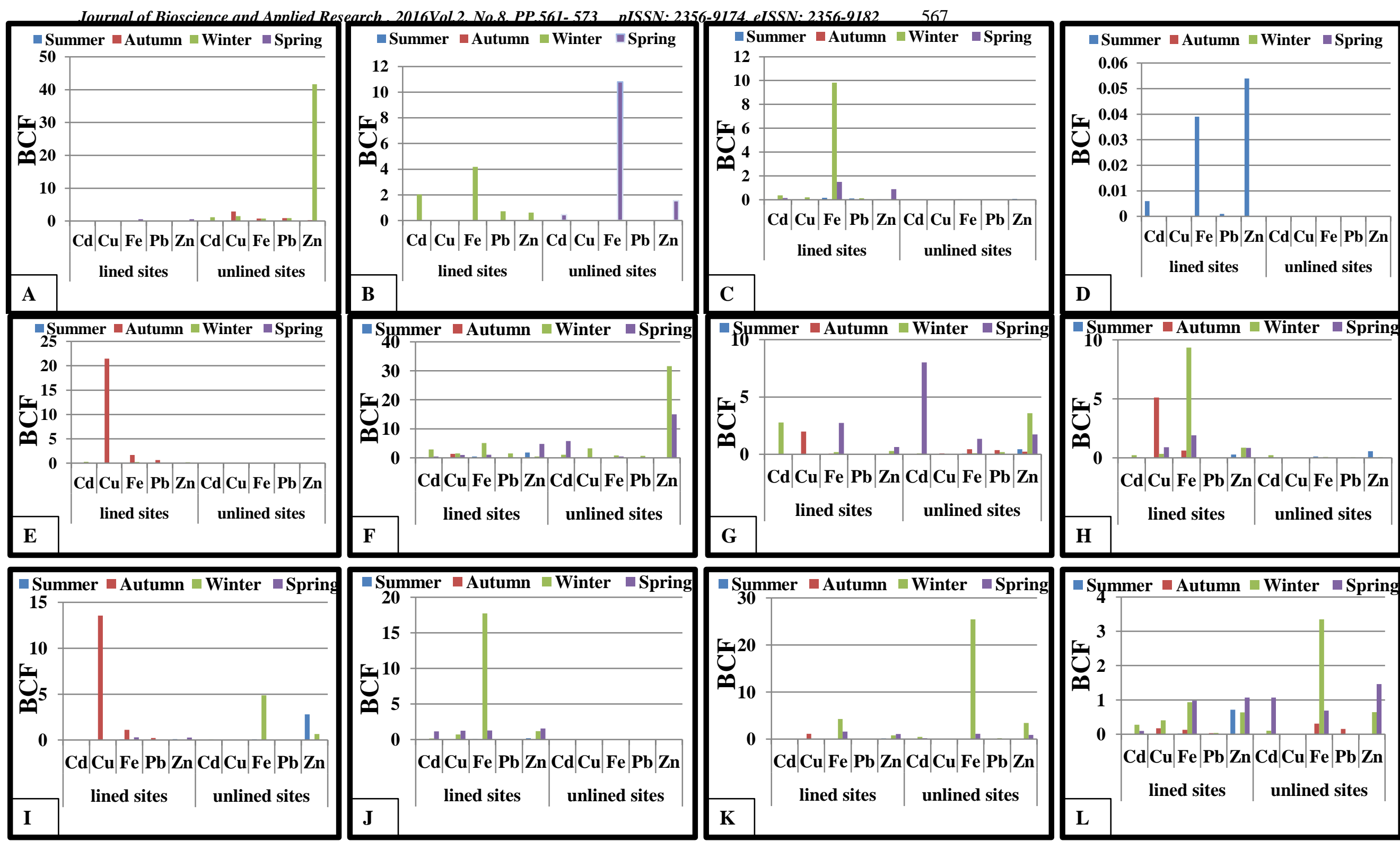

Figure (4A): Bioconcentration factor (BCF) of the metals of the soft tissues (ug.g-1 DW) of snails; (A): Succinia cleopatra, (B): Planorbis planorbis, (C): Helisoma duryi, (D): Biomphalaria glabrata, (E): Bulinus truncatus, (F): Physa acuta, (G): Theodoxus niloticus, (H): Bellamya unicolor, (I): Lanistes carinatus, (J): Gabbiella senaariensis, (K): Melanoides tuberculata and (L): Cleopatra bulimoides in lined and unlined sites of Bahiera Governorate (Nubaria). 


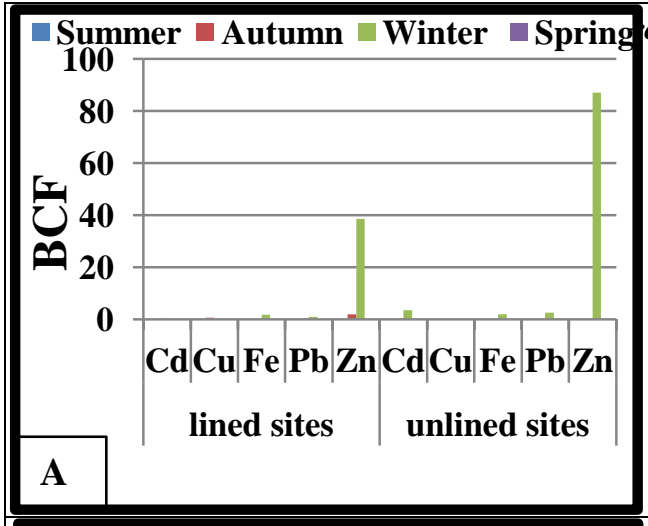

$\square$ Summer $\square$ Autumn $\square$ Winter $\square$ Spring

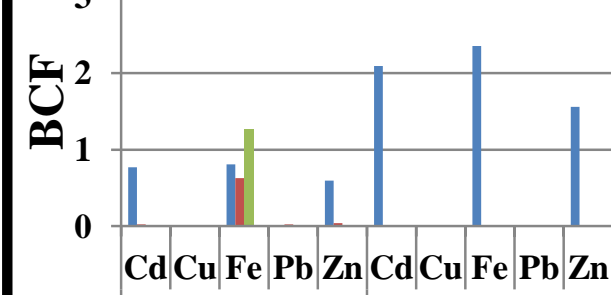

E
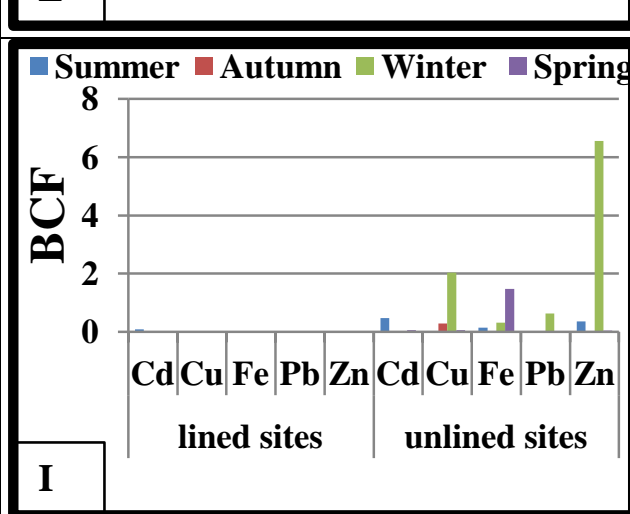
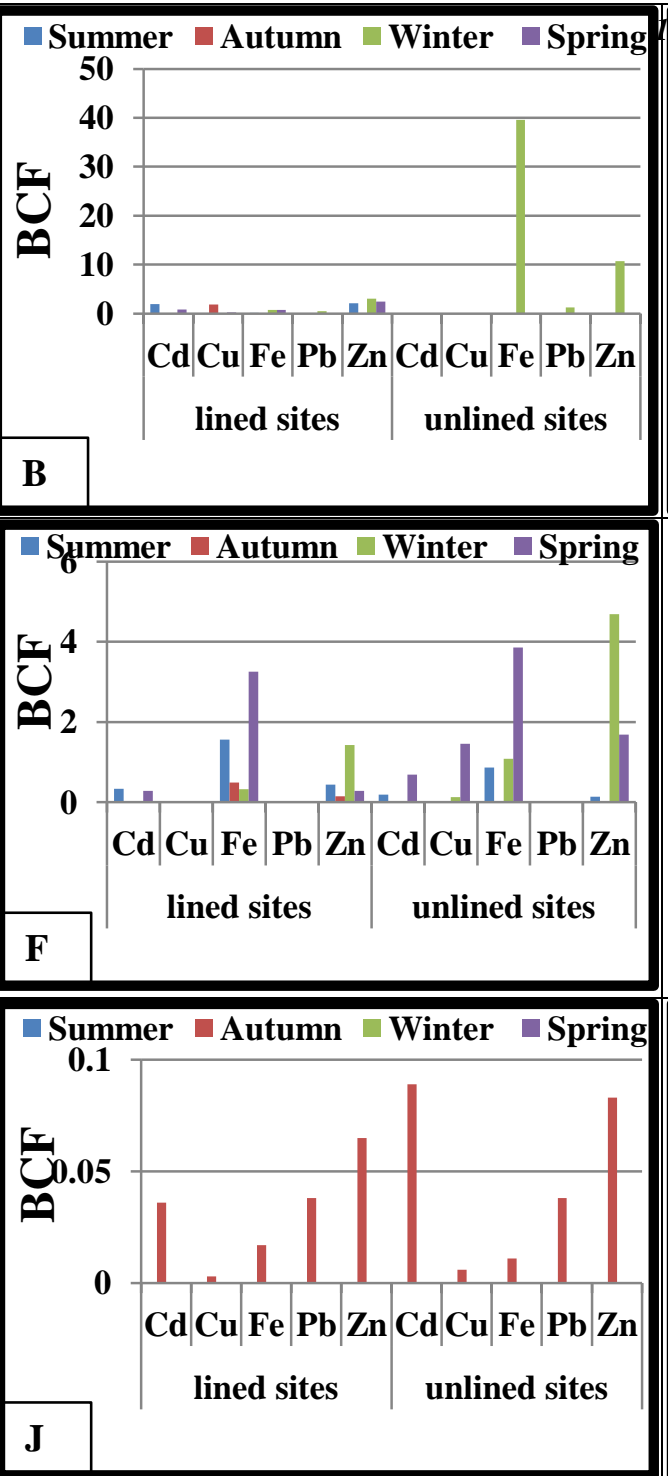

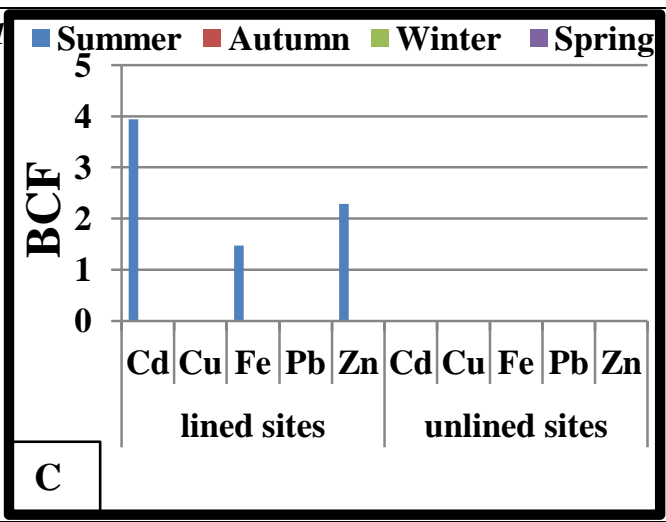

- Summer Autumn $\square$ Winter $\square$ Spring

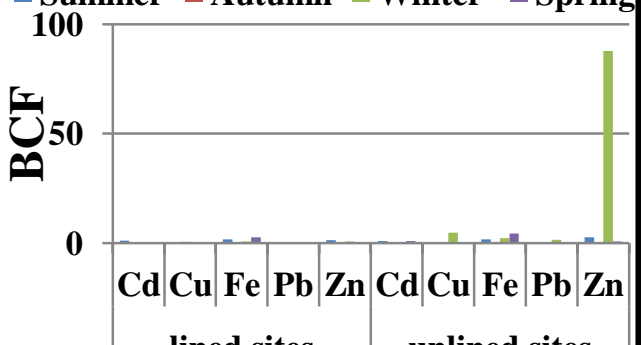

G

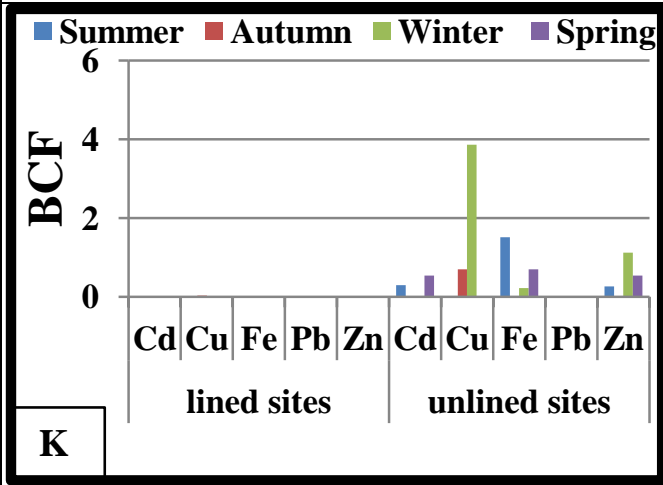

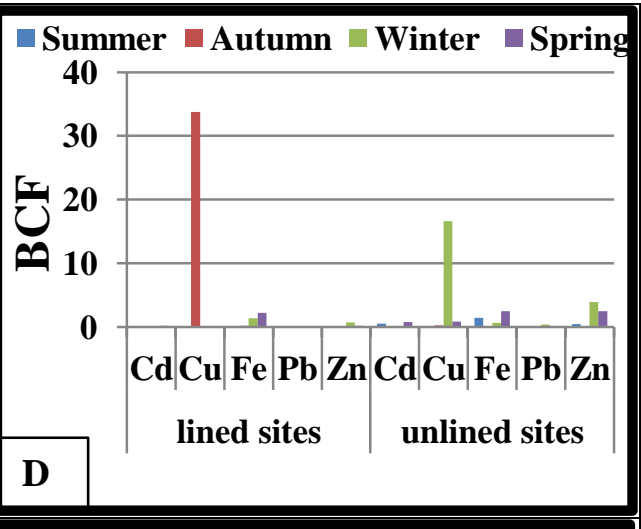

- Summer $\square$ Autumn $\square$ Winter $\square$ Spring
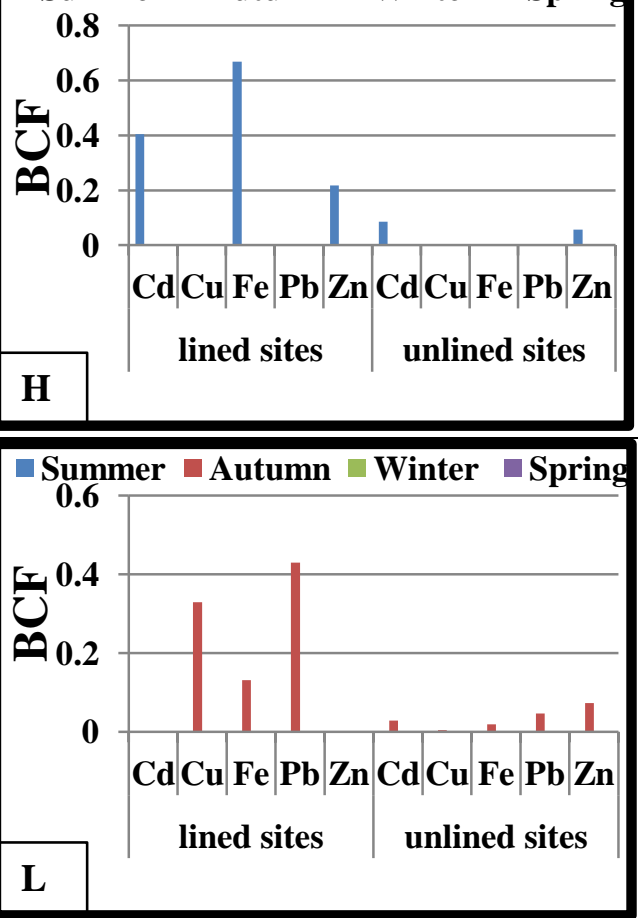

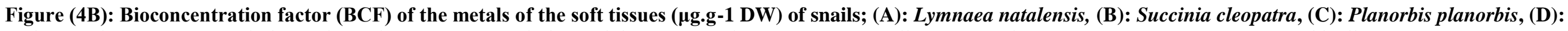

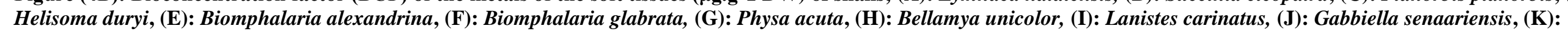

Melanoides tuberculata and (L): Cleopatra bulimoides in lined and unlined sites of Giza Governorate 


\section{Discussion}

The present results of physicochemical measurements indicated that no significant difference between the two tested habitats (lined and unlined water bodies), however, the conductivity of water in lined water bodies was lower than those of unlined ones. These results are in agreement with those of Ismail (2009b) who reported that the physicochemical measurements in lined and unlined water bodies in seven Egyptian governorates (Cairo, Helwan, Giza, Qalioubiya, Ismailiya, Beharia, Dammietta) indicated that no significant difference between the lined and unlined water bodies, however, the conductivity of water in lined water bodies was lower than those of unlined ones. These results also in line with the studies of Yousif et al. (1998a); Abdel-Kader (2001) and Ibrahim et al. (2005).

The current study also showed seasonal variation in the heavy metals concentrations depending on the type of metal and the sites. This may due to the effects of drastic seasonal variations in the river flow and consequent impact on water quality parameters (Sunil, 2001). Also, this is in agreement with the results of Bahnasawy et al. (2009); Siyue and Zhang (2010), who studied the seasonal variation in concentration of the heavy metals in different water courses.

The obtained results also, revealed that, the density of all recorded pulmonate snails in lined sites were lower than those of the unlined ones. This may be explained a considerable advantage to be attached on the side walls of water bodies. On the other hand, the abundance of Prosobranch snails was higher in numbers in the lined sites than those in the unlined. these results agree with the studies of Ismail (2009b) on the distribution and abundance of fresh water snails in lined and unlined water bodies in seven Egyptian governorates (Cairo, Helwan, Giza, Qalioubiya, Ismailiya, Beharia, Dammietta). The collected snails were represented by 12 species belonged to pulmonate snails (Biomphalaria spp, B. truncatus, $P$. acuta, $H$. duryi and $L$. natalensis) and prosobranch (C. bulimoides, L. carinatus, B. unicolor, M. tuberculata, $T$. nilotica, S. Cleopatra and G. senaarensis). The density of all recorded pulmonate snails (except $B$. truncatus) in lined sites were lower than those of the corresponding ones in the unlined ones. In contrast, the abundance of prosobranch snails was higher in numbers in the lined sites than those in the unlined (Ismail, 2009b). These results also go with (Ismail and El-Gamal (2003); Ohmae et al. (2003).

Also the present results recorded that in Nubaria the most abundant snails were Melanoides tuberculata and Theodoxus niloticus and exhibited their maximum percentages in the lined and unlined sites during summer, respectively. While, in Giza Governorate Physa acuta snails had the highest percentages among collected snails approximately at all seasons, and exhibited its maximum percentages during spring in lined and unlined sites. Also, the present results revealed that the richest seasons with different snail species in Nubaria were (the summer and spring) and in Giza Governorate (autumn and winter) at lined and unlined sites, respectively. This is in accordance with El-Kady et al. (2000) who concluded that the highest abundance of collected snails (eg. B. alexandrina, B. truncatus, L. natalensis, $L$. carinatus and $C$. bulimoides) was recorded in March and April (spring season) and in October and November (Autumn season) from irrigation and drainage canals in El-Ismailia governorate. Moreover, Kloos et al. (2004); Owojori et al. (2006); Ntonifor and Ajayi (2007); El-Khayat et al. (2011); Saad et al. (2012) and Abd El-Wakeil et al. (2013) were supported these findings.

Also, the winter was the richest season with different snail species in unlined sites of Giza Governorate. This is in agreement with findings of Owojori et al. (2006) and Afshan et al. (2013). They demonstrated that the cold seasons were more favorable for most snails reproduction than warm ones and that rainy season provides optimum conditions for the availability of freshwater snails, they anticipated that rainy season provides environmental conditions for the propagation of freshwater snails as availability of vegetation; a good food source is increased. Moreover, they postulated that the second peak of snail's density was in November and December.

Concerning the correlations between physicochemical parameters and the collected snails, the obtained data revealed that there was not correlationship between temperature and abundance of snails in lined or unlined sites of Nubaria. This can be explained according to the findings of Oliver and Ansari (1967) as they promulgated that most fresh water snails occur over areas with temperature range of $20-35^{\circ} \mathrm{C}$, flourishing best at constant and warm temperatures. Moreover, species of Lymnaeidae and Llanorbidae could be reared through several generations at about $35^{\circ} \mathrm{C}$ (Harman and Berg, 1971). This is in accordance with the studies of Njoku (2007) and Yirenya et al. (2011).

On the other hand, the correlation between physical parameters and snails collected from Giza Governorate revealed that temperature was negatively correlated only with $H$. duryi in some lined sites. This indicates that these snails are highly sensitive to the elevation in temperature as high temperature causes thermal stress in snail vectors, and also, reduces dissolved oxygen content of the water body 
(Hofkin et al., 1991). This is in coincidence with Hussein et al. (2011); El-Shazly et al. (2012) and Abdel-Wareth (2014).

Regarding to the electrical conductivity (EC), positive correlations were observed between EC and $P$. acuta snails in some lined sites of El-Bahiera (Nubaria) and Giza Governorates, while negative relation was recorded with $L$. carinatus in some unlined sites of Giza Governorate. Moreover, a significant negative correlation was observed between total dissolved solids (TDS) and each of $C$. bulimoides, $P$. acuta and $L$. carinatus in some unlined sites of Nubaria and Giza Governorate, while positive correlations were observed with B. glabrata and $H$. duryi in some lined sites of Giza Governorate. In Nigeria Okwuosa and Ukoli (1980) and Ofoezie (1999) suggeseted that snail density was not significantly affected by temperature, alkalinity, acidity and the presence of major ions but is significantly limited by conductivity and dissolved oygen. Njoku (2011) claimed that conductivity is a limiting factor to snail growth and abundance as snail population was high in medium with conductivity range 50-110 $\mu$ mhos than in medium with lower ranges. These results are in line with that obtained by El-Kady et al. (2000); Saad et al. (2012) and Abdel-Wareth (2014).

In the present study, $\mathrm{pH}$ was positively correlated with $H$. dyri in some unlined sites of Giza Governorate, while negative correlations were recorded between $\mathrm{pH}$ and each of $(H$. dyri and $M$. tuberculata in some lined sites of Nubaria) and (P. acuta and M. tuberculata in some unlined sites of Giza Governorate). This differences may be attributed to other factors which affect the habitat of such snails as Ntonifor and Ajayi (2007) declared that pH didn't influence snails abundance when considered singly. Also, these results are in line with that obtained by Hussein et al. (2011).

Dissolved oxygen was positively correlated with each of $H$. duryi, B. unicolor, B. glabrata and $C$. bulimoides, while it was negatively correlated with $P$. acuta in lined sites of El-Bahiera (Nubaria) and Giza Governorates. In unlined sites of Nubaria dissolved oxygen showed positive relations with both of Planorbis Planorbis and Theoduxus niloticus, while no relations was observed in unlined sites of Giza Governorate. It was found that snails for their metabolic activities need oxygen (WHO, 1965). It was known that dissolved oxgen tension varied with sampling periods and water bodies (Hira, 1970). The author added that, in fast flowing water body, dissolved oxygen was higher than in slow or stagnant water bodies and dissolved oxygen was reduced with the increase in temperature, while increased with rain, which therefore accounted for the high number of snail species in rainy season. Also, Ofoezie (1999) and Abdel-Wareth (2014) recorded the same results.

Concerning the correlations between heavy metals $(\mathrm{Cd}, \mathrm{Cu}, \mathrm{Fe}, \mathrm{Pb}, \mathrm{Zn})$ and the snails in water canals of the studied lined and unlined sites of El-Bahiera (Nubaria) and Giza Governorates, positive correlations were observed, so the more heavy metals concentrations, the more snail species were found. On the other hand, few negative correlations were observed, like: relation between $\mathrm{Cu}$ and each of ( $P$. acuta, M. tuberculata \& L. carinatus), Fe and B. glabrata. The snails can live in a wide range of mineral content in water till they are approached by certain limiting values (Didonato et al., 2003). El -Khayat et al. (2009) revealed that different water courses in Egypt were characterized by the highest concentrations of Cadmium, lead, mercury, sodium and potassium. The author added that the snails disappeared from habitats characterizing by elevation of some toxic elements such as $\mathrm{Cu}, \mathrm{Zn}, \mathrm{Cd}, \mathrm{Pb}$, and $\mathrm{Hg}$ as confirmed by Mahmoud (1994) and Yang et al. (2009). But, as shown in the results of El -Khayat et al. (2009), when snails were in association with plants, they are able to tolerate up to 35.18, 81.54 and $1042 \mathrm{ppb}$ of Cd, $\mathrm{Pb}$ and $\mathrm{Cu}$, respectively. This can be attributed to the formation of microhabitats by plants to which snails move avoiding toxicity.

Results of the current study also showed high variation in BCF values depending on the type of metal and the snail. Generally the iron concentrations determined in the dry weight of the soft tissues of the snails, was the highest metal accumulated in the snail's tissue. While, $P$. acuta and $H$. duryi were the highest snails of accumulated metal contents in the tested sites of El-Bahiera (Nubaria) and Giza Governorates. This can be attributed to the fact that molluscs can tolerate persistent toxic chemicals, such as metals, to a greater extent than other organisms and can serve as effective biomonitors or indicators (Salànki et al., 2003; Liang et al., 2004 and Giarratan et al., 2010; Mahajan, 2015 and Rehman et al., 2016). These results were in accordance with that of Abd-Allah et al. (2003); Yap et al. (2010); Kowalczyk and Czepiel (2013) and Rehman et al. (2016) who determined the accumulation of different heavy metals in the soft body mass of B. glabrata, Faunus ater (Linnaeus), Cochlodina (Cochlodina) laminate, Cepaea nemoralis and (Rapanar apiformis, Chicoreus virgineus and Hemifusus pugilinus) snails, respectively.

It can be concluded that lining have been extremely effective against certain species of snail. Heavy metal analysis in aquatic organisms can provide important information on the degree of environmental contamination and

its impacts. 


\section{References}

AbdAllah, A. T.; Wanas, M. Q. A. and Thompson, S. N. (2003): Dissolved heavy metals, lead, cadmium and mercury, accumulate in the body of the Schistosome vector, Biomphalaria glabrata (Gastropoda: Pulmonata). J. Moll. Stud. 69: 35-41.

Abdel-kader, A. (2001): Effect of ecological parameters on the distribution of snail vectors of schistosomiasis . Egypt. Soc. Parasit., 31: 145-152.

Abd El-Wakeil, K. F.; Obuid-Allah, A.H.; Mohamed, A.H.; Abd El-Aziz, F.A. (2013): Community structure of molluscans in River Nile and its branches in Assiut governorate, Egypt, Egypt. J. Aquat. Res., 39: 193-198.

Abdel-Wareth, M. T. A. (2014): Ecological and biological studies on the effect of some fungi against Biomphalaria alexandrina snails. Ph. D. Thesis, Institute of Environmental Sciences, Inst. Environ. Stud. Res., Ain Shams Univ., Egypt.

Afshan, K.; Beg, M.A.; Ahmad, I; Ahmad, M. M. and Qayyum, M. (2013): Freshwater snail fauna of Pothwar region, Pakistan. Pakistan J. Zool., 45 (1): 227233.

A.O.A.C. (Association of Official Analytical Chemistry) (1995):. Official Method of Analysis. Pesticide and Industrial chemical Residues $16^{\text {th }}$ ed. A.O.A.C. Int., Arlington, Virginia, USA.

Bahnasawy, M.; Khidr, A.A. and Dheina, N. (2009): Remove from marked Records Seasonal variations of heavy metals concentrations in mullet, Mugil cephalus and Liza ramada (Mugilidae) from Lake Manzala, Egypt. J. of Appl. Sci.Rese.,116, 845-852.

Bonaiti, G.; Karimov, A. and Fipps, G. (2011): Evaluation of canal lining projects in the lower Rio Grand Valley of Texas ratings and analysis. Texas water resources Institute Technical report. No.412 Texas A\&M University System College Station, Texas, 77: 843-2118.

Clesceri, L.S; Greenberg, A. E. and Eaton , A.D. (1998): Standard method for the examination of water and waste water in APHA (American Public Health Association). Washington, $20^{\text {th }}$ edition.

Coetzee, L., Du preez, H.H. and Van Vuren, J.H.J. (2002): Metal concentrationsin Clarias gariepinus and Labeo umnratus from the olifants and klein olifants river, Mpumalanga, South Africa: Zinc, Copper, Manganese, Lead, Chromium, Nickel, Aluminium and Irion. Water SA, 28(4):433-448.

Didonato, G.T.; Summers, J.K. and Roush, T.H. (2003): Assessing the ecological condition of a coastal plain watershed using a probabilistic survey design. Environ. Monit. Assess., 85: 1-21.

El-Khayat, H. M.; Ismail, N. M.; Mahmoud, K. M.; Ragb, F. M.; El-Said, K. M.; Mostafa, B. B.; El-Deeb, F. A. and Tantawy, A. A. (2011): Evaluation of some chemical parameters as potential determinants of freshwater snails with special reference to medically important snails in Egypt. World Acad. Sci., Eng. Techn., 59: 1313-1326.

El-Khayat, H.M.M.; Mostafa, B. B.; Mahmoud, K.M.A.; El-Said, K.M. and Ismail, N.M.M. (2009): "The association between fresh water snails, macrophytes and water quality in different water courses in Egypt". New Egypt. J. Med., 40: 381-392.

El- Khayat, H. M.; Eissa, F.I.; Mostafa, M.A. and Flefel, H. E. (2013): Distribution of schistosome intermediate hosts in relation to aquatic plants and physico-chemical characteristics in different watercourses among Kafr El-Sheikh centers, Egypt. Nat. \& Sci. J., 11(12):146-155.

El-Kady, G. A.; Shoukry,A.; Reda, L.A. and ElBadri, Y.S. (2000): Survey and population of dynamics of freshwater snails in newly settled areas of the Sinai Peninsula. Egypt. J. Biol., 2: 42-48.

El-Shazly, A.M.; Nabih, N.; Salem, D. A. and Mohamed, M.Z. (2012): Snail populations in Dakahlia Governorate, Egypt, with special reference to lymnaeids. Egypt. J. Biol., 14: 45-49.

Federici, G.; Shaw, B.J. and Handy, R.D. (2007): Toxicity of titanium dioxide to rain bow trout (Oncorhynchus mykiss): Gillinjury, oxdative stress, and other physiological effects. Aquatic Toxicology, 84: 415430.

Giarratan, O. E.; Duarte, C. A. and Amin, O. A. (2010): Biomarkers and heavy metal bioacumulation in mussels transplanted to coastal waters of the Beagle Chanel. Ecotoxicol. Environm.Saf., 73: 270-279.

Gobas, F. A. P. C. and Morrison, H. A. (2000): Bioconcentration and biomagnifications in the aquatic environment. In Boethling RS, Mackay, D, eds. Handbook of Property Estimation Methods for Chemicals. Environmental and Health Sciences. Boca Raton, FL, USA: Lewis. pp.189-231.

Harman, W. N. and Berg, C. O. (1971): The freshwater Gastropoda of central New York with illustrated keys to the genera and species. Search: Cornell Univ. agric. exp. St., 1: 1-68.

Hira, P. R. (1970): The temperature, $\mathrm{pH}$ and oxygen content of water harboring intermediate snail host of Schistosoma haematobium Niger. J. Sci., 3 (2): 131138.

Hofkin, B. V.; Mkoji, G. M.; Koech D. K. and Loker, E. S. (1991): Control of schistosome-transmitting snails in Kenya by the North American crayfish Procambarus clarkii. Am. J. Trop. Med. Hyg., 45: 339344.

Hussein, M.A.; Obuid-Allah, A. H.; Mahmoud, A.A. and Fangary, H. M.(2011): Population dynamics of freshwater snails (Mollusca: Gastropoda) at Qena 

Governorate, Upper Egypt. Egypt. Acad. J. Biolog. Sci., 3(1): $11-22$.

Ibrahim, A.; Bishai, H. and Khalil, M.T. (1999): Freshwater mollusks of Egypt. Publication of National Biodiversity Unit, Egyptian Environmental Affairs Agency. No. 10, p: 10.

Ibrahim, A.; Yousif, F. and El-Hommossany, K. (2005): Ecological studies on schistosome vector snails in the River Nile at Greater Cairo. J. Environ. Sci., 11: 1937.

Ismail N.M.M. (2009a): "Impact of certain chemical fertilizers on biological, biochemical parameters, protein patterns of Biomphalaria alexandarina snails and on their infection with Schistosoma mansoni." J.Biol. Chem. Envirom. Sci., vol. 4(3), , pp. 499-528.

Ismail, N.M.M.(2009b): Effect of lined and unlined water bodies on the distribution and abunduncaof fresh water snails in certain governorates in Egypt. $J$. Biol. Chem. Environ. Sci., 4(4) : 313-332.

Ismail, N.M. M. and El-Gamal, A. A. (2003): Correlation between snails and fish in fish ponds of World Fish Center (ICLARM) with special reference to snail vectors of schistosomiasis and fascioliasis. J. Egypt. Soc. Parasitol., 33 : 413-424.

Kanakaraju, D. and Anuar, A. (2009): Accumulation and depuration of lead and chromium using Nerita lineata. World Applied Sciences Journal, 6 (9): 1205-1208.

Kariuki, H.C.; Clennon, J.A.; Brady, M.S.; Kitron, U.; Sturrock, R.F.; Ouma, J.H.; Ndzovu, S.T.; Mungai, P.; Hoffman, O.; Hamburger, J.; Pellegrini, C.; Muchiri, E.M. and King , C.H. (2004): Distribution patterns and cercarial shedding of Bulinus nasutus and other snails in the Msambweni area, Coast Province, Kenya. J. Moll. Stud, 69: 349-357.

Kaufmann, P.; Herlihy, A. Elwood, J.; Mitch, M.; Overton, S.; Sale, M.; Messer, J.; Reckhow, K.; Cougan, K.; Peck, D.; Coe, J.; Kinney, A.; Christie, S.; Brown, D.; Hagley, C. and Jager. Y. (1988): Chemical characteristics of streams in the Mid- Atlantic and Southeastern United States. Volume I: Population descriptions and physico-chemical relationships. EPA 600/3-88/021a. U.S. Environmental Protection Agency, Washington, D.C.

Kloos, H.; Passos, L. K. J., LoVerde, P.; Oliveira, R. C. and Gazzinelli, A. (2004): Distribution and Schistosoma mansoni infection of Biomphalaria glabrata in different habitats in a rural area in the Jequitinhonha valley, Minas Gerais, Brazil: Environmental and epidemiological aspects. Mem. Inst. Oswaldo Cruz., 99(7): 673-681.

Kowalczyk, P. D. and Czepiel, M. K. (2013): The effect of accumulation of metals on selected physiological biomarkers in Cochlodina (Cochlodina) laminate (Pulmonata:Clausiliidae) inhabiting urban biocenoses. Envir. Protection and Natural Resources, Vol. 24, 2(56): 45-49.

Liang, L. N.; He, B.; Jiang, G. B.; Chen, D. Y.; Yao, Z. W. (2004): Total Environ. Sci., (324): 105.
Mahmoud, K. A. (1994): The feeding ecology of the snail intermediate host of schistosomiasis in Egypt. M. Sc. Thesis, fac. sci., Cairo Univ.

Mahajan, P.R. (2015): Lead bioaccumulation in whole body tissues of freshwater gastropod snail, Bellamya bengalensis after chronic lead intoxication, Ciotech Journal of Bio-Protocols, 4(2): 15-18.

Nahmani, J.; Lavelle, P. and Rossi, J.P. (2006): Does changing the taxonomical resolution alter the value of soil macroinvertebrates as bioindicators of metal pollution? Soil Biol. Biochem. 38, 385-396.

Njoku, T.R.F. (2007): Ecological studies on some human and animal trematodes in parts of Imo State, Nigeria. Ph. D. Thesis, Imo State Univ., Owerri.

Njoku, T. R. F. (2011): Effect of some physicochemical parameters on abundance of intermediate snails of animal trematodes in Imo state, Nigeria, Research., 3(4): 5-12.

Ntonifor, H.N. and Ajayi, J.A. (2007): Studies on the ecology and distribution of some medically important freshwater snail species in Bauchi state, Nigeria. Int. J. Biol. Chem. Sci., 1(2): 121-127.

Ofoezie, I. E. (1999): Distribution of freshwater snails in the man-made Oyan Reservoir, Ogun State, Nigeria. Hydrobiol., 416: 181-191.

Ohmae, H.; Iwanga, Y.; Nara, T.; et al. (2003): Biological characteristics and control of intermediate snail host of Schistosoma japonicum. Parasitol. Inter., 52: 409417.

Okwuosa, V. N. and Ukoli, F. M. A. (1980): Studies on the ecology of freshwater snail vectors of schistosomiasis in southwest Nigeria: field distribution and relative abundance vis-à-vis physico-chemical environmental factors. Nig. J. Parasitol., 1: 87-122.

Oliver, L. and Ansari, N. (1967): The epidemiology of bilharziasis. (F. K. Mostofi, ed.), 8-14. Springer-Verlag. Berlin Heidelberg. New York.

Owojori, O.J.; Asaolu, S. O. and Ofoezie, I.E. (2006): Ecology of freshwater snails in Opa reservoir and research farm ponds at Obafemi Awolowo University I1 e -Ife, Nigeria. J. Appl. Sci., 6(15): 3004-3015.

Rehman, H. Ur.; Ullah Khan, R. and Sajed, M. (2016): Estimation of Heavy Metal of Mollusca Shell, Water and Soil Collected from Darmalak Dam, Tehsil Lachi District Kohat. World Journal of Zoology, 11 (1): 01-05.

Saad, A. A.; Mostafa, B. B.; Aboul -Magd, S. S. and Azzam, A. M. A. (2012): Impact of some environmental factors on distribution of certain vector snails in five Egyptian Governorates. Egypt. J. Aquat. Biol. \& Fish., 16 (1): 33-40

Salánki, J., Farkas, A. , Kamardina, T. \& Rozsa, K.S. (2003): Molluscs in biological monitoring of water quality Toxicol. Lett., 140-141 (11): 403-410.

Siyue, L.I. and Zhang, Q. (2010): Risk assessment and seasonal variations of dissolved trace elements and heavy metals in the Upper Han River, China. Journal of hazardous materials, 181 (15): 1051-1058. 
Takougang, I.; Barbazan, P.; Tchounwou, P.B. and Noumi, E. (2008): The value of the fresh water snail dipscoop sampling method in macroinvertebrates bioassessment of sugar mill waste water pollution in Mbandjock, Cameron . Int. J. Environ Res Public Health, 51:68-75.

Ursingora, M. and Hladikara, V.(2000): Cadmium in the environment of central Europe. In: Trace elementstheir distribution and effects in the environment,(Eds.) Markert,B. \& Friese, K. E lsevier, Amstrerdam: 88.

Van Dyk, J.C. (2003): Histological changes in the liver of Oreochromis mossambicus (Cichidae) after exposure to cadmium and zinc. M.Sc. Thesis, Rand Afrikaans University, South Africa.

Wang, J. and Chen, C. (2006): Biosorption of Heavy metals by Saccharomyces cerevisiae: a review. Biochemistry Advances. 24, 427-451.

WHO (1965): Snail control in the prevention of bilharziasis. Report of WHO Expert Committee. Geneva: 11-12, 63-85, 123-128, 214.

WHO (1996): Genev. "Agricultural development and vector-born diseases Training and Information Materials on Vector Biology and Control." Slide Set Series. Prepared by WHO in collaboration with FAO, UNEP, and UNCHS. PEEM Secretariat.
Yang, Y.; He, Z.; Lin, Y.; Phlips, E.J.; Stoffella, P.J. and Powell, C.A. (2009): Temporal and spatial variations of copper, cadmium, lead, and zinc in Ten Mile Creek in South Florida, USA Water Environ. Res., 81: 40-50.

Yap, C.K.; Hisyam, M.N.D.; Edward, F.B.; Cheng, W.H. and Tan, S.G. (2010): Concentration of heavy metals in different parts of the gastropod, Fauns ater (Linnaeus), collected from industrial areas of Peninsular Malaysia. Pertanika. J. Trop. Agric. Sci., 33 (1): 45-60.

Yirenya, T. D. R.; Abdul Rashid, A.; Futagbi, G.; Aboagye, I. and Dade, M. (2011): Prevalence of snail vectors of schistosomiasis in the Kpong Head Pond, Ghana. West Afr. J. Appl. Ecol., 18: 39-45.

Yousif, F.; El-Emam, M.; Abdel Kader, A. (1998a): Schistosomiasis in newly reclaimed areas in Egypt. 1-Distribution and population seasonal fluctuation of intermediate host snails J. Egypt. Soc. Parasitol., 28: 915-928.

Zhou, Q.; Zhang, J.; Fu, J.; Shi J. and Jiang, G. (2008): Biomonitoring: An Appealing Tool for Assessment Periophthalmus waltoni Koumans 1941 (Gobiidae: of Metal Pollution in the Aquatic Ecosystem. Analytica Chimica Acta, 606(2): 135-150. 